\title{
Plate XXIX.
}

Fig. 1. Samus anonymus, Gray. Skeleton-spicule; end view (scale $1-12$ th to $1-1800$ inch).

Fig. 2. The same. Skeleton-spicule; lateral view (same scale).

Fig. 3. The same. Flesh-spicule, (large) spined; end view (same scale). $a$, more magnified, to show the spined surface as indicated by the serrated margin; $b$, end of shaft, with smaller and unbranched arms.

Fig. 4. The same. Flesh-spicules (small), bihamate (fibulc). Scale 1-12th to 1-1800th inch. $a$, one more magnified, to show the microspination.

Fig. 5. Corticium Wallichï, Cart. (1874). Skeleton-spicule (scale 1-6th to 1-1800th inch). a a $a$, tubercles; $b$, central canal.

Fig. 6. The same. Skeleton-spicule without tubercles, early stage of development. $a$, central canal. Same scale.

Fig. 7. The same. Flesh-spicule, sceptrellate (same scale).

Fig. 8. The same. Flesh-spicule, more magnified (scale 1-6th to 1-6000th inch). Lateral view. $a$, shaft ; $b b$, radiated disks.

Fig. 9. The same. Flesh-spicule, radiated disks of; end view. . $a$, shaft; $b$, capitate radii.

Fig. 10. Amorphina stellifera, n. sp. $a$, skeleton-spicule; $b$, flesh-spicule, stellate. Scale 1-24th to 1-1800th inch.

Fig. 11. Spinispirula. Flesh-spicule of Spongia Dysoni, Bk., much magnified (scale 1-4th to 1-6000th inch).

Fig. 12. The same. Flesh-spicule from Spirastrella cunctatrix, Sdt., mihi, from the variety on the crab's back (scale 1-12th to 6000th inch).

Fig. 13. Sceptrella. Flesh-spicule of Spongia Loveni, Bocage.

Fig. 14. The same. Flesh-spicule of Latruncula cratera, Bocage.

Fig. 15. The same. Flesh-spicule of Sceptrella regalis, Sdt.

Figs. 16-21. The same. Various forms from the minute detritus of deciduous sponge-spicules in the root-bunch of Euplectella cucumer from the Seychelles. Fig. 16. End view of one, so situated in the detritus.

N.B. All the figures from 16 to 21 respectively are drawn to the same scale, for comparison, viz. 1-12th to 1-6000th inch.

XXXIX.-An Account of a small Series of Coleoptera from the Island of Johanna. By Charles O. Waterhouse.

A SMALL series of Coleoptera has recently been added to the British-Museum collection from the island of Johanna. The specimens were collected by Mr. Bewsher; and among them I have detected three species new to science, for one of which $\mathbf{I}$ propose to establish a new genus. The following species were obtained:-

\section{Cicindela melancholica, Fabr.}

Three examples of this widely distributed species. 


\section{Anisodactylus Bewsheri, sp. n.}

Niger, nitidissimus; thorace postice utrinque creberrime subtiliter punctulato, lateribus rotundatis, margine ipso piceo, angulis posticis obtusis ; elytris vix æneo tinctis, fortiter striatis, striis sublævibus, interstitiis sat convexis, subtilissime crebre punctulatis; antennis, clypeo, palpis pedibusque piceis. $\delta$. Long. $4 \frac{1}{2}$ lin.

Somewhat the form of $A$. binotatus, but a little less parallel at the sides, very shining, black, very slightly tinted with pitchy. Head smooth, the line separating the clypeus scarcely perceptible, the oblique impressions at the ends of this line moderately distinct. Thorax gently convex, one quarter broader than long, almost smooth anteriorly, all the region of the posterior angles densely and very finely punctured, the base in the middle less densely punctured; the sides are distinctly more rounded than in binotatus, especially posteriorly, very slightly impressed above, the impression within the posterior angles scarcely noticeable; the extreme margins are slightly pitchy, not reflexed, the posterior angles are marked, but are very obtuse. Elytra very little broader than the thorax, a little more narrowed at the apex than in binotatus, very slightly tinted with æneous, the striæ very deep, with no visible punctuation, the interstices distinctly convex, (when seen with a strong magnifying-glass) extremely delicately and very closely punctured. Legs pale pitchy; the terminal spur to the anterior tibiæ slender and simple; the basal joint of the tarsi is distinctly narrower than the following, the dilated joints are cordiform, not so transverse as in binotatus.

\section{Aphodius mostus, Fabr.}

There are examples of this species in the Museum collection from Madagascar, Bombay, Ceylon, and Hong Kong.

\section{Apate francisca, Fabr.}

Two specimens appear to be referable to this species.

5. Bostrichus unicornis, sp. $\mathrm{n}$.

Cylindricus, nitidus, niger ; clypeo medio tuberculo fulvo-tomentoso instructo ; thorace ruguloso, antice asperato, utrinque dentibus quinque munito; elytris crebre fortiter punctatis, dorsaliter sublineato-punctatis, apice declivo, margine incrassato, callo subapicali bituberculato, tuberculo exteriore perparum elevato; antennis piceis.

Long. $4 \frac{1}{3}$ lin.

Head dull, densely and finely punctured, the clypeus in 
front furnished in the middle with a small prominence, which is clothed with fulvous hair, and thus appears like a small conical horn. Antennæ pitchy, the club paler. Thorax about as broad as long, slightly narrowed in front of the middle, convex, the posterior angles rounded; the sculpture is of the usual character, but is much less strong than in most of its allies, somewhat closely rugulose punctate posteriorly, gradually becoming more and more asperate anteriorly, where on each side are five small, reflexed, sharp tubercles, placed obliquely in the ordinary way, the anterior one on each side being the anterior angle (which is not prolonged). Elytra scarcely broader than the thorax, two and a quarter times as long, closely and very strongly punctured (the punctures having a tendency to form lines), the intervals not raised; no costæ; the apex obliquely deflexed, scarcely concave, the apical margin much thickened and slightly reflexed, within the margin the surface is nearly smooth; at the subapical callosity there are two tubercles, the outer one obtuse and scarcely raised, the inner one is well developed, acutely conical, directed upwards and slightly towards the suture.

\section{Cratopus ditissimus, Bohem.}

Two examples. This species was originally described from the island of Johanna.

For the next species, which is a new genus of Calandridæ, I propose the name Perissoderes, characterized as follows:-

\section{Perissoderes, n. gen.}

Rostrum robust, rather suddenly deflexed from the base, very gently arcuate, swollen at the base; the antennal scrobes inferior, deep, elongate-ovate. First joint of the funiculus of the antennæ short, obconic; the second as long as broad; third to sixth slightly transverse, the spongy part of the club nearly hidden. Thorax as long as broad, quadrate, scarcely narrower immediately before the anterior constriction than at the base; the base bisinuate, the mesial lobe acute and covering the scutellum. Pygidium longer than broad, deflexed, curvilinear. Prosternum furnished with a strong postcoxal projection, which is emarginate posteriorly. The mesoand metasterna are on the same plane.

There are only two genera, Barystethus, Lac., and Diathetes, Pascoe (Journ. Linn. Soc. 1876, xii. p. 71), which have the scutellum covered by the lobe of the thorax; and this latter has it only partially covered. In the present genus 
the scutellum is invisible. From Barystethus it differs in having the thorax not narrowed anteriorly, the spongy part of the club of the antennæ scarcely at all visible, the pygidium deflexed and not transverse. From Diathetes it differs in having the scutellum entirely concealed; and I do not discern any grooves in the tibiæ as described by Mr. Pascoe.

\section{Perissoderes ruficollis, sp. n.}

Niger, opacus; thorace quadrato, rufo, discrete punctato, margine antico nigro, basi media acute producta; elytris thorace parum latioribus, postice angustatis, subtiliter striatis, striis punctis distantibus, interstitiis planis, uniseriatim punctatis.

Long. (rostr. excl.) $3 \frac{1}{3}$ lin.

Rostrum stout, as long as the thorax, rather strongly and closely punctured at the sides of the base, finely punctured above. Thorax dull rusty red, not very closely or distinctly punctured (although the punctures are not small), as long as broad, suddenly narrowed in front, a trifle broader before the posterior angles than before the anterior constriction, the sides subparallel, obtusely rounded anteriorly, slightly sinuate in the middle, the base bisinuate, the mesial lobe produced over the scutellum, acute at its apex. Elytra at the base a little broader than the thorax, and not quite one third longer, gently narrowed posteriorly ; the strix are very fine, and are interrupted by distinet punctures, which are placed rather far apart; the interstices are flat and furnished with a single regular line of distinct punctures, which are about twice as close together as those on the strix. Pygidium closely and strongly punctured. Femora strongly punctured; tibiæ with finer punctures arranged in lines.

\section{Sternotomis cornutor, Fabr.}

Two examples. This species was originally described by Fabricius as coming from America. It has since been recorded (under the name S. comes) by Prof. Westwood, with doubt, as coming from Madagascar.

See note on the locality and synonyms of this species, Ann. \& Mag. Nat. Hist. 1878, i. p. 424.

\section{Praonetha obsoleta, Fairm.}

A single example which agrees very fairly with the description of this species.

British Museum,

March 7, 1879. 


\section{$2 \mathrm{BHL}$ Biodiversity Heritage Library}

Waterhouse, Charles Owen. 1879. "XXXIX.-An account of a small series of Coleoptera from the Island of Johanna." The Annals and magazine of natural history; zoology, botany, and geology 3, 360-363. https://doi.org/10.1080/00222937908694102.

View This Item Online: https://www.biodiversitylibrary.org/item/81199

DOI: https://doi.org/10.1080/00222937908694102

Permalink: https://www.biodiversitylibrary.org/partpdf/63119

\section{Holding Institution}

Smithsonian Libraries

\section{Sponsored by}

Smithsonian

\section{Copyright \& Reuse}

Copyright Status: Public domain. The BHL considers that this work is no longer under copyright protection.

This document was created from content at the Biodiversity Heritage Library, the world's largest open access digital library for biodiversity literature and archives. Visit BHL at https://www.biodiversitylibrary.org. 